\title{
Efektifitas Perangkat Pembelajaran dengan Model Inkuiri Terbimbing Berbantuan Strategi Peta Konsep untuk Meningkatkan Penguasaan Konsep
}

\author{
${ }^{1 *}$ S. Syarifuddin, ${ }^{2}$ Al Asri, ${ }^{3}$ Atin Mujizatin \\ 1, 2, 3Sekolah Tinggi Agama Islam (STAI) Rawa Aopa, Motaha, Angata, Kabupaten Konawe Selatan, \\ Sulawesi Tenggara 93875, Indonesia \\ *Corresponding Author e-mail: 79syarifuddin@gmail.com
}

Received: December 2019; Revised: February 2020; Published: March 2020

\begin{abstract}
Abstrak
Penelitian ini bertujuan untuk mendeskripsikan kepraktisan dan keefektifan perangkat pembelajaran IPA SMP yang dikembangkan berorientasi pembelajaran inkuiri terbimbing berbantuan strategi concept mapping untuk meningkatkan penguasaan konsep pada materi kalor di siswa SMP. Penelitian ini merupakan penelitian deskriptif dengan rancangan uji coba one group pretest-posttest. Perangkat pembelajaran yang diimplementasikan dalam penelitian ini meliputi Rencana Pelaksanaan Pembelajaran (RPP), Lembar Kerja Siswa (LKS), Buku Siswa, dan Lembar Penilaian (LP). Subyek penelitian adalah 10 siswa kelas VII SMP Negeri 19 Surabaya. Hasil penelitian menunjukkan bahwa (1) kepraktisan perangkat pembelajaran yang ditinjau dari keterlaksanaan pembelajaran berkategori baik, aktivitas siswa paling dominan adalah proses memecahkan masalah, serta respons siswa terhadap pembelajaran dinyatakan positif dan (2) keefektifan perangkat pembelajaran yang ditinjau dari ketuntasan hasil belajar produk, proses, dan psikomotor berkategori tuntas, perilaku berkarakter dan keterampilan sosial berkategori baik. Berdasarkan hasil penelitian tersebut dapat disimpulkan bahwa perangkat pembelajaran IPA SMP yang digunakan praktis, dan efektif untuk meningkatkan penguasaan konsep siswa SMP pada materi kalor.
\end{abstract}

Kata Kunci: Inkuiri, Concept Mapping, Kalor, Penguasaan Konsep

\section{The Effectiveness of Learning Tools with Guided Inquiry Model Assisted by Concept Map Strategies to Improve Concept Mastery}

\begin{abstract}
This study aims to describe the practicality and effectiveness of the Junior High School natural learning learning tools that are developed oriented towards guided inquiry learning assisted with concept mapping strategies to improve the junior high school students' concepts mastery in heat material. This research is a descriptive study with a one group pretest-posttest trial design. The learning tools implemented in this study include the Learning Implementation Plan (RPP), Student Worksheets (LKS), Student Books, and Assessment Sheets (LP). The research subjects were 10 grade VII students of SMP Negeri 19 Surabaya. The results showed that (1) the practicality of learning devices in terms of good learning implementation, the most dominant student activity was the process of solving problems, and students' responses to learning were positive and (2) the effectiveness of learning devices in terms of completeness of learning outcomes of products, processes, and psychomotor categorized as complete, characterized by good behavior and social skills. Based on the results of these studies it can be concluded that the science learning tools of junior high school that are used practically, and effectively to improve the junior high school students' concept mastery on heat material.
\end{abstract}

Keywords: Inquiry, Concept Mapping, Heat, Concepts Mastery

How to Cite: Syarifuddin, S., Asri, A., \& Mujizatin, A. (2020). Efektifitas Perangkat Pembelajaran dengan Model Inkuiri Terbimbing Berbantuan Strategi Peta Konsep untuk Meningkatkan Penguasaan Konsep. Jurnal Penelitian dan Pengkajian Ilmu Pendidikan: e-Saintika, 4(1), 38-53. doi:https:/ / doi.org/10.36312/e-saintika.v4i1.197 


\section{PENDAHULUAN}

Pendidikan merupakan hal yang sangat urgen dalam mengukur tingkat kemajuan bangsa. Keberhasilan suatu bangsa sangat ditentukan dari keberhasilan bangsa itu dalam mengkonstruksi sistem pendidikannya. Mengkonstruksi sistem pendidikan yang baik tidak terlepas dari keberhasilan dalam proses belajar mengajar. Pengembangan perangkat pembelajaran merupakan upaya dalam meningkatkan mutu pendidikan, untuk mengembangkan suatu perangkat pembelajaran, ada beberapa hal yang harus diperhatikan oleh pendidik dalam mengembangan suatu perangkat, di antaranya: a) Pembuatan buku ajar siswa. b) Rencana Pelaksanaan Pembelajaran (RPP), c) Pembuatan Lembar Kegiatan Siswa (LKS), d) Pembuatan dan penggunaan alat atau media, e) Pembuatan kisi-kisi soal, f) Pembuatan tes hasil belajar. Apabila hal ini dilaksanakan oleh pendidik dengan baik, maka akan dapat meningkatkan kualitas pembelajaran sehingga secara otomatis dapat meningkatkan kualitas pendidikan.

Perubahan kurikulum adalah sebuah keniscayaan, seiring perkembangan zaman serta untuk menjawab kebutuhan bangsa dan masyarakat. Hal ini tercermin pada evaluasi dan perubahan dari kurikulum KTSP 2006 menjadi Kurikulum 2013. Pendekatan saintifik menurut Kurikulum 2013 adalah menerapkan sains untuk memecahkan masalah di kehidupan sehari-hari.

Berdasarkan tujuan pembelajaran sains, maka kegiatan belajar mengajar sains, termasuk bidang studi IPA semestinya diarahkan pada kegiatan yang mendorong siswa belajar secara aktif, baik fisik, maupun mental. Selama KBM, diharapkan keterlibatan siswa menemukan dan membangun sendiri pengetahuannya melalui interaksi dengan lingkungannya.

Berdasarkan kondisi yang demikian maka perlu dikembangkan suatu pendekatan pembelajaran yang lebih berkualitas untuk dapat meningkatkan penguasaan konsep IPA siswa. Salah satu alternatifnya adalah dengan pemilihan model pembelajaran yang tepat.

Hasil TIMMS 2015 (Trends in International Math and Science Survey), yang menempatkan siswa Indonesia dalam bidang sains di urutan ke 40 dengan skor 406 dari 42 negara, pada kategori kemampuan berpikir advance yaitu mengolah informasi, membuat generalisasi menyelesaiakan masalah non rutin, mengambil kesimpulan data skor ini turun 21 angka dibandingkan TIMSS tahun 2007 (Pusat Penilaian Pendidikan Balitbang Kemdikbud, 2011).

Hasil penelitian Wahyudi (2013) menunjukkan bahwa penguasaan konsep fisika siswa yang belajar menggunakan inkuiri terbimbing dengan peta konsep lebih tinggi daripada hasil belajar siswa yang belajar menggunakan pembelajaran inkuiri terbimbing. Sementara itu penelitian Saptorini (2008) menunjukkan bahwa guru yang memiliki pemahaman tentang model inkuiri yang rendah berdampak pada kemampuan siswa di dalam membuat peta konsep juga rendah. Penelitian ini dilakukan pada guru kimia di kabupaten Demak yang diberi pelatihan Model inkuri oleh peneliti pada pokok materi elektrokimia. Uraian penelitian di atas menunjukkan bahwa kelemahan dari penelitian tersebut model pembelajaran tersebut kurang dipadukan dengan media pembelajaran sehingga siswa merasa jenuh karena terlalu banyak menyita waktu ditambah materi yang cukup rumit.

Berdasarkan karakteristik dari inkuiri terbimbing yang telah dikemukakan maka tentunya akan lebih mudah bila dalam proses penemuanya, juga didukung oleh cara belajar (How-to learn?) yang efektif. Mengetahui cara belajar yang efektif adalah 
sebuah keharusan agar konsep atau pengetahuan baru yang dipelajari dapat dengan mudah diserap oleh otak dan dapat dipanggil kembali jika siswa membutuhkanya. Permasalahan yang banyak terjadi pada peserta didik justru disebabkan karena tidak tahu dan tidak difasilitasi untuk tahu cara belajar yang menyenangkan, akibatnya mereka selalu merasa belajar itu membosankan, belajar itu melelahkan, belajar itu sulit dipahami, belajar itu membuat otak cepat penuh, belajar itu membuat kantuk, belajar itu sulit konsentrasi dan sebagainya. Berdasarkan identifikasi penyebab masalah yang dihadapi oleh siswa pada mata pelajaran IPA perlu adanya strategi belajar yang dapat meningkatkan penguasaan konsep. Strategi yang diprediksikan mampu membangun dan meningkatkan penguasaan konsep dengan strategi organisasi, yaitu dengan menggunakan peta konsep. Peta konsep dapat membantu peserta didik berpikir secara holistik karena peta konsep bekerja untuk memahami keterkaitan gagasan. Salah satu hasil representasi visual adalah fokus pada mengembangkan dan mengingat asosiasi yang relevan, bukan konsep menghafal atau dicat dengan cara yang lebih linear.

Berdasarkan uraian tersebut, penelitian ini bertujuan untuk mendeskripsikan kepraktisan dan keefektifan perangkat pembelajaran dengan model inkuiri terbimbing berbantuan strategi peta konsep untuk meningkatkan penguasaan konsep pada materi kalor.

\section{METODE}

\section{Rancangan penelitian}

Rancangan uji coba digunakan untuk mengujicobakan hasil pengembangan perangkat pembelajaran fisika model inkuiri terbimbing dengan menerapkan strategi concept mapping. Rancangan penelitian menggunakan rancangan one-group pretestposttest design. Rancangan penelitian ini melibatkan satu kelompok yang diobservasi pada tahap pretest $\left(\mathrm{O}_{1}\right)$ yang kemudian dilanjutkan dengan perlakuan tertentu $(X)$ dan posttest $\left(\mathrm{O}_{2}\right)$ (Creswell, 2010). Rancangan one-group pretest-posttest design dapat ditulis dengan bentuk:

$$
\mathrm{O}_{1} \times \mathrm{O}_{2}
$$

dengan:

$\mathrm{O}_{1} \quad$ : uji awal (pretest) untuk mengetahui penguasaan konsep siswa terhadap materi pelajaran sebelum pembelajaran.

$\mathrm{O}_{2} \quad$ : uji awal (posttest) untuk mengetahui penguasaan konsep siswa terhadap materi pelajaran sesudah pembelajaran.

$X \quad$ : perlakuan pembelajaran dengan menggunakan perangkat pembelajaran model inkuiri terbimbing dengan menggunakan strategi Concept Mapping.

\section{Instrumen Penelitian}

\section{Lembar Pengamatan Keterlaksanaan Pembelajaran.}

Penilaian kualitas keterlaksanaan proses belajar mengajar ditentukan dengan menghitung rata-rata skor penilaian yang diberikan kedua pengamat. Persentase keterlaksanaan pembelajaran yang dilakukan guru selama kegiatan belajar mengajar berlangsung ditentukan dengan membandingkan jumlah aspek yang terlaksana dengan jumlah seluruh aspek pada rancangan pembelajaran inkuiri terbimbing yang dilakukan guru selama kegiatan belajar mengajar dikalikan 100\%. Rumus yang digunakan sebagai berikut:

$$
\text { Percentage of Agreement }(R)=\left\{1-\frac{A-B}{A+B}\right\} \times 100 \% \text { (Borich dalam Ibrahim, 2005) }
$$


Keterangan:

$\mathrm{A}=$ Frekuensi aspek yang teramati oleh pengamat yang memberikan frekuensi tinggi

B = Frekuensi aspek yang teramati oleh pengamat yang memberikan frekuensi rendah

Instrumen dikatakan baik jika mempunyai koefisien korelasi reliabilitas $\geq 0,75$ atau 75\% (Borich dalam Ibrahim, 2005).

Lembar Pengamatan Aktivitas Siswa

Lembar ini digunakan untuk mengamati aktivitas siswa selama menerapkan pembelajaran IPA dengan menggunakan perangkat pembelajaran yang telah dikembangkan. Adapun hasil validasinya Instrumen pengamatan aktivitas pada Pelaksanaan pembelajaran pertama Untuk menentukan reliabilitas lembar penilaian aktivitas siswa digunakan rumus percentage of agreement:

Percentage of Agreement $(R)=\left\{1-\frac{A-B}{A+B}\right\} \times 100 \%$ (Borich dalam Ibrahim, 2005)

\section{Keterangan:}

A = frekuensi aspek aktivitas siswa yang teramati dengan frekuensi tinggi

$\mathrm{B}=$ frekuensi aspek aktivitas siswa yang teramati dengan frekuensi rendah

Instrumen dikatakan baik jika mempunyai koefesien korelasi reliabilitas $\geq 0,75$ atau 75\% (Borich dalam Ibrahim, 2005).

Lembar Angket Respons Siswa

Angket respons siswa digunakan untuk mengukur pendapat siswa terhadap ketertarikan, perasaan senang dan keterkinian, serta kemudahan memahami komponen-komponen: materi/isi pelajaran, format materi ajar, kegiatan dalam LKS, suasana belajar, cara guru mengajar dan pendekatan pembelajaran yang digunakan. Angket respon siswa diberikan pada siswa setelah seluruh KBM selesai. Berdasarkan hasil analisis respons siswa terhadap pengembangan perangkat pembelajaran dan pelaksanaan pembelajaran dengan model inkuiri terbimbing berbantuan teknik concept mapping didapatkan hasil bahwa sebanyak $86.67 \%$ siswa merespon dengan kriteria kuat Instrumen Tes Hasil belajar (penguasaan Konsep)

Instrumen ini digunakan untuk mengetahui kemampuan siswa dalam pemahaman konsep materi kalor. Instrumen ini berupa tes pemahaman konsep. Soal yang dikembangkan sebanyak 13 butir soal pilihan ganda dengan empat option dan 2 soal uraian. Tes pemahaman konsep siswa yang digunakan harus mempunyai indeks sensitivitas yang baik.Untuk menghitung sensitivitas butir soal digunakan rumus sebagai berikut:

Keterangan:

$$
S=\frac{R_{a}-R_{b}}{T}
$$

(Grounlund dalam Ibrahim, 2005)

$S$ = indeks sensivitas soal

$\mathrm{T}=$ banyak siswa yang mengikuti tes

$R_{a}=$ jumlah siswa yang menjawab benar pada tes akhir

$R_{b}=$ jumlah siswa yang menjawab benar pada tes awal

Hasil penilaian terhadap pengembangan perangkat tes penguasaan konsep yang terdiri atas 13 soal pilihan ganda dan 2 soal essai, oleh para ahli secara rata-rata menunjukkan bahwa dari aspek isi perangkat ini mendapatkan skor 3.64 dan soal tes dinyatakan sangat valid, dari aspek bahasa dan penulisan soal mendapatkan skor 3.71 dan dinyatakan sangat valid (Ratumanan \& Laurens, 2006). 
Berdasarkan 14 soal yang dikembangkan mendapat nilai kesensitifan sama dengan atau di atas 0.30 (Gronlund \& Linn, 1995). Penerapan hasil pengembangan perangkat model inkuiri terbimbing berbantuan strategi Concept Mapping dapat meningkatkan ketuntasan tujuan pembelajaran aspek pengetahuan.

\section{HASIL DAN PEMBAHASAN \\ Kepraktisan Perangkat Pembelajaran}

Kepraktisan perangkat pembelajaran yang digunakan dalam penelitian ini ditinjau berdasarakan keterlasanaan pembelajaran dan aktivitas siswa selama pembelajaran berlangsung yang diamati oleh dua orang pengamat. Hasil observasi keterlaksanaan pembelajaran dan aktivitas siswa disajikan pada Tabel 1 dan Tabel 2. Tabel 1. Keterlasanaan pembelajaran RPP Tahap 1 dan RPP Tahap 2

\begin{tabular}{|c|c|c|c|c|c|c|}
\hline \multicolumn{7}{|c|}{ Tahap 1} \\
\hline \multirow{2}{*}{ Kegiatan } & \multicolumn{3}{|c|}{ RPP 1} & \multicolumn{3}{|c|}{ RPP 2} \\
\hline & Skor & Kategori & Reliabilitas (\%) & Skor & Kategori & Reliabilitas (\%) \\
\hline Awal & 3.83 & Sangat Baik & 95.24 & 4 & Sangat Baik & 100 \\
\hline Inti & 3.42 & Baik & 91.02 & 3.71 & Sangat Baik & 91.84 \\
\hline Penutup & 3.67 & Sangat Baik & 100 & 4 & Sangat Baik & 100 \\
\hline Suasana kelas & 3.5 & Sangat Baik & 100 & 4 & Sangat Baik & 100 \\
\hline Pengelolaan waktu & 2.5 & Cukup Baik & 80 & 3.5 & Sangat Baik & 85.71 \\
\hline \multicolumn{7}{|c|}{ Tahap 2} \\
\hline \multirow{2}{*}{ Kegiatan } & \multicolumn{3}{|c|}{ RPP 1} & \multicolumn{3}{|c|}{ RPP 2} \\
\hline & Skor & Kategori & Reliabilitas (\%) & Skor & Kategori & Reliabilitas (\%) \\
\hline Awal & 3.75 & Sangat Baik & 92.86 & 4 & Sangat Baik & 100 \\
\hline Inti & 3.20 & Baik & 94.29 & 3.70 & Sangat Baik & 91.43 \\
\hline Penutup & 3.25 & Sangat Baik & 92.85 & 3.5 & Sangat Baik & 85.71 \\
\hline Suasana kelas & 4 & Sangat Baik & 100 & 4 & Sangat Baik & 100 \\
\hline Pengelolaan waktu & 2 & Cukup Baik & 100 & 3.5 & Sangat Baik & 85.71 \\
\hline
\end{tabular}

Berdasarkan Tabel 1 diketahui bahwa semua tahap-tahap kegiatan yang ada di dalam RPP 1 tahap 1 pada uji coba I di kelas VII terlaksana dan secara rata-rata keseluruhan skor keterlaksanaannya adalah 3.61 dengan kategori baik (Ratumanan dan Laurens, 2011). Instrumen keterlaksanaan RPP mempunyai rata-rata reliabilitas 94.41\% dan berkategori baik (Borich, 1994), hal serupa juga ditemukan pada keterlaksanaan RPP 2 yang secara rata-rata skor keterlaksanaan adalah 3.49 dengan kategori cukup baik dengan rata-rata reliabilitas $92.83 \%$ dan berkategori baik.

Tabel 2. Hasil pengamatan aktivitas siswa.

\begin{tabular}{|c|c|c|c|c|c|c|c|}
\hline & \multirow{2}{*}{$\mathrm{N}$} & \multicolumn{3}{|c|}{ RPP 1} & \multicolumn{3}{|c|}{ RPP 2} \\
\hline & & Rata-rata & $(\%)$ & Reliabilitas (\%) & Rata-rata & $(\%)$ & Reliabilitas (\%) \\
\hline Total & 10 & 231 & 100 & 833.15 & 228 & 100 & 830.62 \\
\hline Rata-rata & 10 & 25.66 & 11.11 & 92.57 & 25.33 & 11.11 & 92.29 \\
\hline
\end{tabular}

Semua aktivitas siswa terlaksana sesuai model inkuiri terbimbing. Instrumen pengamatan aktivitas pada RPP 1 mempunyai rata-rata reliabilitas $92.57 \%$ dan berkategori baik, sedangkan untuk RPP 2 mempunyai rata-rata reliabilitas $92.29 \%$ dan berkategori baik (Borich, 1994).

Berdasarkan hasil analisis keterlaksanaan penggunaan perangkat pembelajaran diamati oleh dua orang pengamat. Pengamatan dilakukan selama 4 kali pertemuan yang merupakan implementasi dari RPP 1 dan RPP 2, tiap RPP terdiri atas 2 tahap. RPP tahap I terdapat tiga kegiatan yaitu pendahuluan, kegiatan inti, dan kegiatan penutup. Pada uji coba I ini secara rata-rata keseluruhan skor keterlaksanaan RPP tahap I adalah 3.6 dengan kategori baik (Ratumanan dan Laurens, 2011). 
Skor rata-rata yang tinggi dan dengan kategori baik tersebut dikarenakan semua tahap pembelajaran terlaksana dan beberapa hal lain yaitu: 1) pada kegiatan pendahuluan; pada tahap penyajian tujuan $\mathcal{E}$ motivasi, guru memulai PBM dengan memberikan motivasi mengenai gejala alam yang berkaitan dengan kalor dalam kehidupan, misalnya siswa mengamati video yang berkaitan dengan siklus hidrologi guna menumbuhkan kesadaran dan rasa syukur atas kebesaran Tuhan, dari hal itu guru sudah melakukan penilaian terhadap bentuk ekspresi kekaguman yang terpancar dari siswa setelah mengamati video tersebut. Bentuk rasa syukur yang ditumbuh kembangkan selama proses pembelajaran pada diri siswa merupakan perwujudan dari menguatnya interaksi vertikal dengan Tuhan Yang Maha Esa. 2) pada kegiatan inti, guru mendapatkan skor dengan kategori adalah baik. Kategori yang baik tersebut dikarenakan: (1) siswa diberi kesempatan untuk mengamati fenomena yang akan menggiring pemikiran dan ide siswa untuk merumuskan permasalahan. Proses mengamati fenomena alam, fenomena sosial, dan fenomena seni budaya, kemudian bertanya dan menalar hasil pertanyaan tersebut merupakan proses siswa untuk menjadi kreatif (Setyaningrum, 2013); (2) Masalah yang dirumuskan siswa menjadi titik awal proses penyelidikan siswa. Proses mencari jawaban sementara berupa sebuah hipotesis atas permasalahan tersebut adalah dengan cara mengeksplorasi pengetahuan awal siswa dari membaca buku ajar siswa kemudian menuangkanya dalam Concept Mapping, tujuanya agar siswa dari awal sudah aktif mengkonstruksi pengetahuan mereka sendiri. Diawali dengan membaca buku ajar dengan sub-bab yang telah ditentukan, siswa diharapkan mampu mengekstrak konsep-konsep penting dari bacaan dengan menggaris bawahi ide-ide pentingguna menghasilkan keyword berupa kata-kata inklusif dan proposisi yang digunakan dalam membuat concept mapping. Hal ini sesuai dengan teori "pengatur kemajuan" seperti yang diungkapkan Ausuble bahwa menggarisbawahi ide-ide utama dalam suatu situasi pembelajaran yang baru merupakan bentuk pengorganisasian awal guna mengkaitkan ide-ide baru tersebut dengan pengetahuan yang telah ada pada pembelajaran (Riyanto, 2009). Agar concept mapping yang dibuat siswa tidak terlalu jauh keluar konteks, maka pada pertemuan pertama guru memberikan bimbingan berupa penentuan kata-kata inklusif untuk mengisi cabang utama.

Pembuatan concept map diawal pembelajaran ini merupakan sintaks yang terintegrasi dengan inkuiri terbimbing, yang merupakan bentuk eksplorasi kepada siswa agar mau berpastisipasi aktif menemukan konsep awal sebelum memulai penyelidikan. Hal ini juga sesuai dengan teori belajar penemuan oleh Bruner menyarankan agar siswa hendaknya belajar melalui partisipasi secara aktif dengan konsep-konsep dan prinsip-prinsip, agar mereka memperoleh pengalaman, dan melakukan eksperimen-eksperimen yang mengizinkan mereka menemukan prinsipprinsip mereka sendiri (Slavin, 2011).

Pembuatan rancangan percobaan (termasuk di dalamnya menuangkan rumusan masalah, dan hipotesis), menuangkan hasil percobaan, analisis dan kesimpulan.Proses mengidentifikasi masalah dan membuat hipotesis memang dilakukan terbimbing oleh guru mengingat tingkat perkembangan kognitif siswa belum sampai pada taraf belajar abstrak. Hasil identifikasi masalah berupa pertanyaan penelitian yang harus dijawab dengan mengumpulkan informasi sebanyak-banyaknya dengan proses inkuiri (penyelidikan). Masalah dan pertanyaan 
ini yang mendorong siswa melakukan penyelidikan untuk menentukan jawabannya (Acevedo, et al., 2010; Bao, et al., 2009). .

Strategi Concept mapping yang diaplikasikan menggunakan bantuan software Edrawmax, software ini dipakai hanya pada saat mengenalkan cara membuat peta konsep. Software ini sangat praktis dan efektif dalam menuangkan ide-ide dalam concept map, terutama mengenai fleksibilitas pengubahan (editing), pengaturan ruang yang bebas dan tidak perlu khawatir jika tidak simetris, lebih mengoptimalkan kecepatan berpikir, dan lebih fleksibel serta variatif dalam presentasi (Windura, 2013). Penggunaan software Edrawmax juga merupakan cara yang sukses untuk mendukung eksplorasi dan presentasi ide-ide anak-anak, serta memberikan fokus yang berguna bagi siswa untuk mengatur pikiran mereka dan untuk menyajikan informasi secara jelas dan menarik (Ralston \& Cook, 2007).

RPP tahap II juga dibagi dalam tiga kegiatan yaitu pendahuluan, inti dan penutup. Pada uji coba I ini secara rata-rata keseluruhan skor keterlaksanaan RPP bagian II adalah 3.49 dengan kategori baik (Ratumanan dan Laurens, 2011).

Skor rata-rata yang tinggi dan dengan kategori baik tersebut dikarenakan semua tahap pembelajaran terlaksana dan beberapa hal lain yaitu: (1) pada kegiatan inti, siswa mulai melakukan percobaan setelah sebelumnya mereka mengeksplorasi konsep awal dan merancang percobaan. Siswa merasakan euphoria selama pembelajaran karena sangat asyik ketika melaksankan percobaan mengenai kalor. Hal ini sesuai yang dinyatakan oleh teori yang dikemukakan Piaget bahwa pendidikan yang optimal membutuhkan pengalaman yang menantang bagi pebelajar sehingga proses asimilasi dan akomodasi dapat menghasilkan pertumbuhan intelektual (Hergenhan dan Olson, 2009). Asimilasi adalah proses perolehan informasi dari luar, dan pengasimilasiannya dengan pengetahuan dan perilaku kita sebelumnya. Akomodasi meliputi proses perubahan (adaptasi) skema lama untuk memproses informasi dan objek baru di lingkungannya (Solso, 2008). Harapan dengan pembelajaran model inkuiri terbimbing, siswa akan merasakan tantangan dengan melaksanakan kegiatan penyelidikan dalam pembelajaran fisika untuk melakukan asimilasi dan akomodasi pengetahuan yang dimiliki; (2) pada tahap menganalisis data guru membimbing agar siswa mampu menalar dengan menganalisis data hasil eksperimen penuh ketelitian dan tanggung jawab. Setelah itu guru dapat membimbing untuk menyimpulkan hasil percobaan dengan penuh kejujuran dan tanggung jawab. Penerapan pembelajaran berbasis inkuiri terbimbing tidak hanya dapat meningkatkan kemampuan siswa dalam memahami materi tetapi juga dapat meningkatkan kemampuan keterampilan proses sains dan kerja ilmiah (Ambarsari, et al., 2012; Ariesta dan Supartono, 2011). Ausbel menjelaskan pembelajaran berdasarkan hafalan tidak banyak membantu siswa di dalam memperoleh pengetahuan, pembelajaran oleh guru harus membangun pemahaman dalam struktur kognitifnya, pembelajaran haruslah bermakna bagi siswa untuk menyelesaikan permasalahan kehidupannya (Suyono dan Hariyanto, 2011); (3) pada tahap yang terakhir guru memberi kesempatan perwakilan kelompok menyajikan dan mengkomunikasikan hasil percobaan dengan jujur dan tanggung jawab; dan guru dapat mengomentari jalannya diskusi dan memberikan penguatan serta meluruskan yang kurang tepat. hal ini sesuai dengan hasil penelitian David (2006) yang menyatakan bahwa pembelajaran inkuiri terbimbing merupakan kegiatan melibatkan para siswa, mempromosikan restrukturisasi informasi membantu siswa mengembangkan pemahaman konsep fisika secara utuh dan terbangunnya proses sains dan sikap ilmiah. 
Berdasarkan pembahasan di atas dapat diketahui bahwa perangkat Rencana Pelaksanaan Pembelajaran (RPP) yang digunakan merupakan perangkat yang reliabel dan memiliki kategori baik sehingga layak untuk memperoleh data pembelajaran model inkuri terbimbing berbantuan strategi concept mapping dalam meningkatkan penguasaan konsep siswa.

Hasil pengamatan aktivitas siswa pada uji coba I diketahui bahwa pada aktivitas memperhatikan penjelasan, bertanya pada guru, membaca dan menggarisbawahi konsep-konsep penting, membuat Concept Mapping, merumuskan masalah, merumuskan hipotesis percobaan, menentukan variabel percobaan, merancang dan melakukan percobaan, menganalisis data hasil percobaan,merumuskan kesimpulan hasil percobaan, menyajikan dan mengkomunikasikan hasil percobaan, mengalami peningkatan tiap siklus RPP. Ferlina, Suyatna, dan Maharta (2012) menyatakan bahwa model pembelajaran inkuiri yang digunakan oleh guru dapat membuat siswa untuk lebih aktif dalam kegiatan pembelajaran, menanamkan dasar-dasar berfikir ilmiah pada diri siswa, sehingga dalam proses pembelajaran ini siswa lebih banyak aktif dalam memecahkan masalah. Peningkatan aktivitas siswa tiap siklus RPP menunjukkan bahwa siswa dalam kegiatan pembelajaran berada di lingkungan sosial, mereka terus menerus belajar melalui interaksi dengan orang lain di sekitar mereka. Vigotsky berpendapat bahwa perkembangan proses hidup bergantung pada interaksi sosial dan pembelajaran sosial berperan penting untuk perkembangan kognitif (Khulthau dan Todd, 2008).

Aktivitas siswa tahap 1 yang meliputi: melakukan percobaan, mengumpulkan data dan menganalisis data, menyimpulkan hasil percobaan, menyajikan hasil lewat presentasi, perilaku tidak relevan, ada dua aktivitas yang paling menonjol yaitu: 1) melakukan percobaan ; dan 2) menyajikan hasil lewat presentasi. Pada aktivitas melakukan percobaan siswa dikondisikan untuk merasa tertantang untuk menyelesaikan permasalahan yang ada di LKS Eksperimen sehingga siswa melakukan kegiatan yang ada di LKS dengan penuh motivasi. Khulthau (2010; 2007) menyatakan inkuiri terbimbing menuntut siswa untuk mengembangkan langkah kerja dalam memecahkan masalah yang telah diberikan oleh guru melalui LKS jenis challenge activity, inkuiri terbimbing masih memegang peranan guru dalam memilih topik/bahasan, pertanyaan dan menyediakan materi, akan tetapi siswa diharuskan untuk melakukan penyelidikan, menganalisis, dan sampai kepada kesimpulan.

Pada aktivitas siswa tahap 2 yang meliputi: Mendengarkan penjelasan dan bimbingan guru, Bertanya kepada guru untuk memperoleh bimbingan, Membaca dan menggarisbawahi konsep-konsep penting, mmbuat Concept Mapping dari konsepkonsep penting, Membaca isi bacaan pada LKS lalu menentukan kata-kata yang paling inklusif dan kurang inklusif serta proposisi (konektor) yang menghubungkan setiap konsep-konsep yang ada. Strategi Concept Mapping, ada dua aktivitas yang persentasenya paling menonjol yaitu: 1) Membaca dan menggarisbawahi konsepkonsep penting; 2) Membuat Concept Mapping. Kedua aktivitas ini merupakan bagian dari strategi concept mapping, siswa dikondisikan agar mampu mengkonstruksi sendiri pemahaman mereka melalui mengeksplorasi membaca buku ajar, kemudian mengekstrak konsep-konsep penting untuk dijadikan keyword dalam pembuatan concept mapping, setiap cabang utama akan menghasilkan anak cabang baru, dan tiap anak cabang kemungkinan juga dapat menghasilkan anak cabang yang lain sehingga dihasilkan pancaran pikiran menyeluruh yang lebih terorganisir dan lebih relevan serta dapat menghubungkan banyak ide (Al Jarf, 2009). 
Ada beberapa siswa masih belum bisa dilepas secara penuh karena belum terbiasa dalam pembelajaran IPA kegiatan penyelidikan di laboratorium. Guru menjadi fasilitator dalam pembelajaran model inkuiri terbimbing hal ini sejalan dengan pemikiran Barthlow (2011) bahwa aturan guru di inkuiri terbimbing adalah memfasilitasi dan membimbing siswa untuk mengetahui pembelajaran yang dilaksanakan. Hal ini terjadi karena siswa merasa bisa melakukan percobaan dan sudah terbiasa dengan kegiatan yang menggunakan keterampilan proses sains dalam kegiatan penyelidikan.

Pada aktivitas menyajikan hasil penyelidikan tiap kelompok hanya diberikan waktu untuk presentasi \pm 10 menit. Hal itu dikarenakan diperlukan waktu-waktu tambahan di luar estimasi waktu presentasi seperti pada saat membuat peta konsepnya di papan tulis untuk presentasi, serta waktu saat pergantian kelompok. Pada penyajian hasil yang pertama, ditemukan fakta bahwa siswa membuat concept mapping dengan tidak urut, posisi dalam meletakan cabang juga berpengaruh pada urutan presentasi, misalnya cabang yang seharusnya berada pada haerarki ke-2 di pasang pada haerarki ke-3 akhirnya hasilnya menjadi tidak runut. Pada pertemuan selanjutnya, siswa mulai memperbaiki kesalahan tersebut dengan mengurutkan terlebih dahulu cabang-cabang yang akan dipresentasikan.

\section{Keefektifan Perangkat Pembelajaran}

Hasil belajar siswa

Tes Penguasaan Konsep diberikan dua kali tes yaitu sebelum pembelajaran (pretest) dan setelah pembelajaran (posttest) dengan model pembelajaran inkuiri terbimbing berbantuan teknik concept mapping. Hasil dari tes penguasaan konsep siswa digunakan untuk menentukan ketuntasan hasil belajar aspek pengetahuan siswa. Hasil ketuntasan belajar siswa disajikan pada Tabel 3 berikut.

Tabel 3. Tingkat Ketuntasan tes penguasaan konsep

\begin{tabular}{|c|c|c|c|c|c|c|c|c|c|c|}
\hline & \multicolumn{4}{|c|}{ Rerata Pretest } & \multicolumn{4}{|c|}{ Rerata Posttest } & \multirow{2}{*}{$\begin{array}{l}\text { Rerata } \\
\text { N-Gain }\end{array}$} & \multirow{2}{*}{ Ket } \\
\hline & Nilai & Skor & Predikat & Ket & Nilai & Skor & Predikat & Ket & & \\
\hline Rerata & 24,85 & 1 & $\mathrm{D}$ & $\begin{array}{l}\text { Tidak } \\
\text { tuntas }\end{array}$ & 84.55 & 3.44 & $\mathrm{~B}+$ & Tuntas & 0.8 & Tinggi \\
\hline
\end{tabular}

Nilai pretest digunakan untuk mengetahui aspek pengetahuan awal siswa. Nilai posttest yang diperoleh siswa menggambarkan tentang hasil belajar pengetahuan siswa setelah mengikuti pembelajaran model inkuiri terbimbing berbantuan strategi concept mapping. Penerapan hasil pengembangan perangkat dapat meningkatkan ketuntasan indikator pembelajaran aspek pengetahuan. N-Gain rata-rata dari kelas VII adalah 0,80 dengan kategori tinggi (Hake, 1999). Penerapan hasil pengembangan perangkat model inkuiri terbimbing dapat meningkatkan penguasaan konsep fisika serta dapat meningkatkan ketuntasan tujuan pembelajaran aspek pengetahuan. Hal ini sesuai dengan teori penemuan yang dikemukakan oleh Bruner, bahwa untuk meningkatkan prestasi belajar (dalam hal ini yang dimaksud adalah penguasaan konsep) maka siswa harus tahu bagaimana mentransformasi pengetahuan secara aktif. Seperti pada pembelajaran dengan model inkuiri terbimbing berbantuan strategi Concept Mapping, siswa diajarkan untuk mentransformsi pengetahuan dengan jalan penyelidikan serta dibantu media Concept Map yang mempermudah mengorganisasikan konsep yang telah diperoleh, sehingga informasi tersebut dapat bertahan lama dalam pikiran siswa. 
Peningkatan yang ditunjukkan oleh hasil analisis dengan menggunakan N-Gain menunjukkan tentang penerapan dari pengembangan perangkat pembelajaran IPA model inkuiri terbimbing berbantuan strategi concept mapping efektif dalam meningkatkan penguasaan aspek pengetahuan pada materi kalor. Hasil diperkuat dengan Wenning (2011) bahwa pembelajaran melalui inkuiri membuat siswa belajar sains dengan pemahaman yang sangat baik, dan hasil penelitian Maliyah (2012), Astuti (2013), dan David (2006) yang menyatakan bahwa pembelajaran dengan menggunakan proses pembelajaran inkuri terbimbing dapat meningkatkan kognitif siswa serta El-Mona \& El-Khalick (2008) yang menemukan bahwa menemukan bahwa peserta dalam kelompok Concept Mapping mencapai hasil yang signifikan secara statistik pada semua kategori sasaran (pemahaman konseptual dan penalaran praktis) dan tingkat prestasi (dasar, cakap, dan mahir).

Tes hasil belajar aspek keterampilan yang diujikan berguna mengukur keterampilan proses sains siswa. Dalam pembelajaran Fisika, siswa sebagai subjek belajar perlu dibekali dan dilatih mengembangkan keterampilan proses sains melalui serangkaian proses dan kerja ilmiah, sehingga tumbuh dan tertanam sikap keilmuan pada diri siswa (Azis, 2014). Keterampilan proses yang dinilai dalam penelitian ini adalah merumuskan masalah, membuat hipotesis, menentukan variabel percobaan, merancang percobaan, melakukan percobaan, menganalisis data percobaan, dan membuat kesimpulan. Topik tes hasil belajar aspek keterampilan tersebut adalah Hubungan kalor dengan Jenis Zat.

Berdasarkan analisis hasil belajar aspek keterampilan secara keseluruhan dapat dilihat bahwa semua siswa telah mencapai skor minimal 2.66 ( $\geq 75$ ). Artinya, model pembelajaran inkuiri terbimbing dengan strategi Concept Mapping pada materi kalor sudah bisa memberi ketuntasan pada hasil belajar aspek keterampilan terutama keterampilan proses sains siswa. Hal ini dimungkinkan, karena beberapa alasan yaitu: 1) siswa telah diajarkan keterampilan proses sains, di luar pembelajaran (sebelum pembelajaran dimulai), sehingga ketika pembelajaran dimulai siswa telah siap dengan kemampuan awal keterampilan proses sains tersebut. 2) siswa terus dilatih selama 4 pertemuan dengan 2 topik LKS yang berbeda, untuk melakukan kegiatan yang melatih keterampilan proses sains, meskipun masih ada beberapa siswa yang mengalami kesulitan dalam menggunakan keterampilan proses sains terutama dalam merumuskan hipotesis dari suatu percobaan. Solusi yang memungkinkan untuk diterapkan dalam rangka mencapai ketuntasan tujuan pembelajaran keterampilan proses sains adalah memberikan lebih banyak latihan yang berkaitan dengan tujuan pembelajaran tersebut.

Ketuntasan indikator hasil belajar aspek keterampilan menunjukkan tentang penerapan dari pengembangan perangkat pembelajaran IPA model inkuiri terbimbing berbantuan strategi Concept Mapping efektif dalam membantu ketuntasan keterampilan proses sains siswa pada materi kalor. Hasil temuan pada penelitian ini sesuai dengan temuan dari penelitian Astuti dan Setiawan (2013); Johansyah (2013); dan Praptiwi, Sarwi, Handayani (2012) yang menyimpulkan bahwa pembelajaran fisika dengan menggunakan model inkuiri terbimbing pada topik kalor dapat meningkatkan keterampilan proses sains. Secara keseluruhan, berdasarkan hasil belajar aspek keterampilan sudah mampu menggunakan keterampilan proses sains. Siswa masih memerlukan latihan secara berkelanjutan agar mereka terbiasa untuk menggunakan keterampilan proses sains dalam memecahkan masalah-masalah dalam pelajaran sains dan hasil belajar yang diharapkan dapat dicapai lebih optimal. 
Peningkatan penguasaan konsep, selain sejalan dengan kemampuan siswa dalam melatihkan aspek keterampilan juga sejalan dengan peningkatan hasil belajar aspek sikap siswa. Hasil belajar aspek sikap siswa diperoleh dari pengamat sikap siswa selama pembelajaran yang meliputi sikap religi dan sikap sosial siswa. Sikap religi yang diamati selama pembelajaran adalah rasa syukur. Sikap sosial yang diamati adalah teliti, jujur dan bertanggung-jawab. Rasa syukur terhadap kebesaran Tuhan secara rata-rata dari 10 siswa yang teramati selama pembelajaran adalah 76,25\% selama empat pertemuan dengan kategori Baik (Kemendikbud, 2013). Hal ini mengindikasikan bahwa pembelajaran model inkuiri terbimbing dapat mengembangkan rasa syukur siswa meskipun tidak berkembang secara drastis karena hanya dilaksanakan selama empat kali pertemuan.

Sikap teliti siswa teramati dengan melakasanakan pembelajaran inkuiri terbimbing berbantuan strategi concept mapping adalah 78,75\% selama empat pertemuan dengan kategori Baik (Kemendikbud, 2013). Tahap ke-1 RPP 1 siswa menunjukan sikap kurang teliti terutama dalam menyiapkan bahan yang digunakan untuk melakukan percobaan dan saat melakukan percobaan sehingga masih diperlukan banyak bimbingan. Guru mengingatkan agar lebih teliti dalam merancang dan melakukan percobaan. Pada RPP selanjutnya siswa telah menunjukan peningkatan sikap teliti ditandai dengan peningkatan persentase sikap teliti dari $67.5 \%$ pada RPP1 menjadi $90 \%$ pada RPP2. hal itu menunjukan bahwa model pembelajaran inkuiri terbimbing dengan strategi concept mapping meningkatkan sikap teliti siswa.

Sikap jujur secara rata-rata teramati selama melaksanakan pembelajaran inkuiri terbimbing berbantuan strategi concept mapping adalah $76.25 \%$ selama empat pertemuan dengan kategori Baik (Kemendikbud, 2013). RPP 1 tahap 1 ada dua siswa yang jalan-jalan mencari contekan dan bertanya ke kelompok lain. RPP1 tahap 2 ada satu siswa yang tidak jujur dengan masih berjalan mencari contekan. Akhir pembelajaran guru mengingatkan agar jujur dengan apa yang kita lakukan termasuk mengembalikan alat dan bahan yang kita pinjam. Pada pertemuan selanjutnya semua siswa jujur dalam menuliskan percobaan dan tidak mencontek. Hal ini mengindikasikan bahwa dengan menggunakan model inkuiri terbimbing siswa dapat lebih jujur selama percobaan.

Sikap tanggung jawab secara rata-rata teramati selama melakasanakan pembelajaran inkuiri terbimbing adalah $78,75 \%$ selama empat pertemuan dengan kategori Baik (Kemendikbud, 2013). RPP1 tahap 2 ada anggota kelompok siswa yang tidak membantu mengerjakan concept map, kemudian pada akhir pembelajaran guru mengingatkan bahwa tanggung jawab masing-masing siswa akan mempengaruhi proses sains kelompok. Pada RPP2 tahap 2 jumlah siswa yang tidak aktif mengerjakan concept map menjadi berkurang, dan sebagian besar bertanggung jawab atas kelompok terutama pada saat melakukan percobaan. Hal ini mengindikasikan bahwa dengan menggunakan model inkuiri terbimbing siswa dapat lebih bertanggung jawab selama percobaan.

Informasi tentang hasil pengamatan pengembangan sikap siswa (yaitu rasa syukur, teliti, jujur dan tanggung jawab) yang terintegrasi dalam proses pembelajaran materi kalor mengindikasikan bahwa melalui pembelajaran dengan menggunakan model inkuiri terbimbing, sikap siswa dapat teramati dan dapat dikembangkan dengan kategori baik (Kemendikbud, 2013). Hal tersebut dikarenakan siswa terusmenerus memperlihatkan sikap yang dinyatakan dalam indikator secara konsisten 
yang ditunjukan dengan skor perkembangan yang mengalami kenaikan melalui pengamatan oleh penilaian.

Berdasarkan pengamatan sikap siswa selama pembelajaran tergolong berkembang, meski tidak semua siswa berkembang karena hanya 4 kali pertemuan. Tidak ada sikap siswa yang masuk dalam kategori kurang. sikap yang teramati minimal pada kategori cukup baik. Hasil ini sesuai dengan hasil penelitian yang dilakukan Budiarso (2013) bahwa perangkat pembelajaran fisika model inkuiri terbimbing dapat mengembangkan sikap ilmiah antara lain sikap disiplin, rasa ingin tahu, disiplin, kerja sama, jujur dan tanggung jawab. Jadi perangkat pembelajaran fisika model inkuri dapat mengembangkan rasa syukur, teliti, tanggung jawab, dan jujur.

Secara keseluruhan, terdapat keterkaitan antara peningkatan penguasaaan konsep yang mendukung aspek hasil belajar pengetahuan, peningkatan ketuntasan keterampilan tiap RPP dan peningkatan pengembangan sikap siswa setelah pembelajaran model inkuiri terbimbing berbantuan tstrategi concept mapping. Hal ini sesuai dengan tujuan perancangan kurikulum 2013 yaitu memperkuat kompetensi siswa dari sisi aspek pengetahuan, keterampilan dan sikap secara utuh (Kemendikbud, 2013)

Berdasarkan hasil analisis respon siswa terhadap pengembangan perangkat pembelajaran (yang meliputi: buku ajar siswa dan lembar kegiatan siswa), serta pelaksanaan pembelajaran dengan model inkuiri terbimbing berbantuan strategi concept mapping secara rata-rata didapatkan hasil bahwa sebanyak $86.67 \%$ siswa merespon dengan kriteria kuat (Riduwan, 2010). Siswa merespon positif.

Persentasi paling tinggi terdapat pada respon, (1) siswa lebih mudah memahami bahasa, penampilan dan isi (materi) dalam buku ajar (2) siswa merasa guru telah memberikan bimbingan mengenai cara membuat concept mapping dengan baik. (3) siswa merasa lebih mudah dan menyenangkan mencatat dengan strategi concept mapping.. (4) siswa merasa lebih mandiri dalam memperoleh pengetahuan, jika menggunakan strategi Concept Mapping. Ada empat siswa yang kurang maksimal dalam pengerjaan LKS, memahami buku siswa, tes penguasaan konsep. Solusinya dengan memberi latihan dan pendekatan personal yang lebih dalam pembelajaran.

Berdasarkan hasil analisis dapat diketahui bahwa respon siswa terhadap pengembangan perangkat dan pelaksanaan pembelajaran selama uji coba I adalah positif dengan kategori sangat kuat dan kuat. Hal ini berarti siswa mendukung, merasa senang, dan berminat terhadap pembelajaran dengan menggunakan perangkat hasil pengembangan model inkuiri terbimbing berbantuan strategi concept mapping untuk meningkatkan penguasaan konsep siswa. Hasil ini sesuai dengan hasil penelitian dari Nugroho (2012); Maliyah, dkk. (2012); dan Putri, dkk. (2012) yang menyatakan bahwa dengan menerapkan model Guided Inquiry (inkuiri terbimbing) mendapat respon yang sangat baik dalam meningkatkan motivasi belajar siswa.

Respon yang sangat kuat ditunjukan siswa pada aspek kemandirian dalam memperoleh pengetahuan. Siswa merasa dengan strategi Concept Mapping, mereka mampu meningkatkan kemandirian terutama dalam memaksimalkan sumber daya yang mereka miliki.

\section{Kendala-kendala Selama Proses Pembelajaran}

Selama pelaksanaan pembelajaran model inkuiri terbimbing ditemukan beberapa hambatan atau kendala. Kendala yang pertama adalah waktu pembelajaran 
kurang karena siswa datang telat dari perpindahan jam pelajaran. Solusi yang diberikan adalah dengan menyuruh siswa agar tidak terlambat dan efisiensi waktu. kendala yang kedua adalah siswa belum terbiasa mengikuti pembelajaran dengan model inkuiri terbimbing yang menggunakan keterampilan proses dalam kegiatan di laboratorium. Kendala ini diatasi dengan memberikan pengarahan dan informasi kepada siswa tentang pembelajaran dengan model inkuiri terbimbing berbantuan strategi Concept Mapping dengan harapan siswa lebih mudah dalam mengikuti pembelajaran. Banyak model hierarki siswa dalam membuat concept map. Solusi yang diberikan adalah menyuruh siswa agar Menyuruh siswa agar mengenal jenis-jenis concept map. Kendala yang keempat adalah siswa Siswa kesulitan dalam menentukan kata-kata paling inklusif yang menunjang ide-ide dalam cabang-cabang concept mapping. Mengarahkan siswa untuk menuliskan kata-kata yang telah digarisbawahi pada lembaran kosong secara runut, kemudian memilih kata-kata yang paling inklusif.

\section{KESIMPULAN}

Berdasarkan hasil analisi data dan pembahasan, maka dapat dibuat kesimpulan bahwa perangkat pembelajaran fisika model inkuiri terbimbing berbantuan strategi concept mapping yang dikembangkan sudah valid memperoleh skor rata-rata 3,5 dengan kategori baik, praktis yang ditunjukan dengan peningkatan hasil belajar ( $\mathrm{N}$ Gain) dengan skor 0,8 dengan kategori tinggi, dan efektif yang ditunjukan oleh respons siswa yang didapatkan hasil $86.67 \%$ siswa merespons dengan kriteria kuat, sehingga perangkat pembelajaran model inkuiri berbantuan peta konsep layak digunakan untuk meningkatkan penguasaan konsep siswa SMP.

\section{SARAN}

Beberapa saran dapat dikemukakan oleh peneliti berdasarkan penelititan yang telah dilakukan adalah sebagai berikut.

1. Penerapan rencana pelaksanaan pembelajaran sudah baik namun guru harus lebih bisa mengelola waktu selama pembelajaran agar pembelajaran bisa berjalan lebih efektif dan efisien. Disarankan peneliti-peneliti selanjutnya memberikan gambaran dengan jelas kepada siswa dan guru tentang pembelajaran menggunakan model inkuiri terbimbing berbantuan strategi concept mapping.

2. Peneliti lain perlu melatih siswa untuk lebih mengembangkan kemampuan yang diperlukan pada pembelajaran yang menggunakan kurikulum 2013, yaitu penggunaan keterampilan proses dan keterampilan membuat concept map dalam pembelajaran untuk melakukan kegiatan penyelidikan. Pengenalan awal bisa dilakukan pada waktu khusus, agar saat proses pembelajaran siswa tidak kesulitan menyelesaikan LKS dan melakukan penyelidikan.

3. LKS dan buku ajar yang digunakan pada saat pembelajaran lebih baik dibagikan kepada siswa sebelum pembelajaran dilaksanakan sehingga siswa lebih mudah dalam memahami LKS tersebut.

4. Secara keseluruhan pengembangan perangkat pembelajaran model inkuiri terbimbing berbantuan strategi concept mapping dapat mengembangkan sikap religi dan sosial siswa SMP pada materi kalor sehingga diharapkan dilakukan penelitian lanjutan pada materi fisika yang lain dan dengan pengembangan sikap siswa yang lainnya.

5. Penggunaan concept map dapat menjadi rekomendasi, untuk digunakan pada materi fisika yang lain atau pada materi pelajaran lain, karena sangat membantu 
mengorganisasikan pengetahuan yang telah diperoleh siswa selama dan setelah pembelajaran

6. Pengembangan perangkat pembelajaran model inkuiri sebaiknya dipadukan dengan beberapa aplikasi pembelajaran yang telah tersedia guna memudahkan dan menghindarkan sikap jenuh dari peserta didik

\section{UCAPAN TERIMAKASIH}

Penelitian ini tidak menerima hibah khusus dari agensi pendanaan mana pun di sektor publik, komersial, atau nirlaba.

\section{DAFTAR PUSTAKA}

Adi, M. R., Sudiana, I. W., Resana, I. Dw. Pt. (2012). Pengaruh Model Pembelajaran Inkuiri Terbimbing Berbantukan Teknik Peta Konsep Terhadap Pemahaman Konsep IPA Siswa Kelas V SD Desa KaliAsem.Singaraja: PPs. PGSD.Universitas Ganesha.Tersedia di ejournal.undiksha.ac.id/index.php/JJPGSD/article/viewFile/3058／2532. Diakses tanggal 15 April 2014.

Anderson, L \& Krathwohl, D. (2001). A Taxonomy for Learn ing, Teaching, And Assessing. New York: Addison Wesley Longman, Inc.

Arends, R.I. (2008). Belajar untuk Mengajar. Penerjemah oleh Soetjipto, H.P \& Soetjipto, S.M. Yogyakrta: PT. Pustaka Pelajar.

Arends, R.I. (2009). Learning to Teach. 9th ed. New York: The McGraw-Hill Compaines. Ari, N. M., Dantes, N, dan Tastra, I. D. K. (2012). Pengaruh Model Pembelajaran Inkuiri Terbimbing Berbantuan Peta Konsep terhadap Hasil Belajar IPA Kelas V. Singaraja: PPs. PGSD. Universitas Ganesha. Tersedia di e journal. undiksha. ac.id/index.php/JJPGSD/article/viewFile/3058/2532. Diakses tanggal 20 Mei 2014.

Ariadi, B.Y. (2010). Metode Pembelajaran Inkuiri. Tersedia di http://bambang ariadi. Wordpress.com/2010/02/12/metode pembelajaran inkuiri/. Diakses tanggal 20 November 2014.

Badan Penelitian dan Pengembangan Nasional Kementrian Pendidikan dan Kebudayaan. (2011). Ringkasanstudi PISA 2011. Jakarta: Depdiknas

Badan Penelitian dan Pengembangan Nasional Kementrian Pendidikan dan Kebudayaan. (2013). Kosep pendekatan saintifik. Jakarta : Depdiknas

Balitbang Kemendikbud. (2010a). Survai Internasional PISA. Tersedia di http:// litbang.kemendikbud.go.id/ diakses tanggal 10 Agustus 2014.

Balitbang Kemendikbud. (2010b). Survai Internasional TIMSS. Tersedia di http://Litbang.kemendikbud.go.id/ diakses tanggal 10 Agustus 2014.

BSNP. (2010). Paradigma Pendidikan Nasioanl Abad XXI. Badan Standar Nasional Pendidikan Versi 1. Jakarta.

Buzan, T. (2006). Buku pintar mind map. Jakarta: PT. Gramedia Pustaka Utama

Dahar, R.W. (1988). Teori- Teori belajar. Jakarta: Erlangga.

Depdiknas. (2003). Standar Kompetensi Mata Pelajaran Kimia SMA E MA. Jakarta: Departemen Pendidikan Nasional.

Dimyati \& Mudjiono. (2009). Belajar dan Pembelajaran. Jakarta: Rineka Cipta.

Edmondson, K. (2000). Assessing Science Understanding Through Concept Maps. In J. Mintzes, J. Wandersee, \& J. Novak (Eds). Assessing Science Understanding: A Human Constructivist View. San Diego, CA: Academic Press.

Fenton, E. (1966). Teaching The New Social Studies In Secondary School. An Inductive Aproach. Bloomington: Indiana University Press. 
Fleischman, H. L., Pelezar, M.P., and Shelley, B.F. (2010). Highlight From PISA 2009. Performance of U.S. 15-Years-Old Student in Reading Mathematics, and Science Literacy in an International Context. NSES. U. S. Departement of Education.

Giancolli, (2001). Fisika Jilid I. Jakarta: Erlangga.

Ibrahim, M. (2002).Pelatihan Terintegrasi Berbasis Kompetensi Guru Mata Pelajaran Biologi. Pengembangan Perangkat Pembelajaran. Surabaya: Direktorat Sekolah Lanjutan Tingkat Pertama, Pendidikan dasar dan Menengah. Departemen Pendidikan Nasional.

Ibrahim, M. (2005). Asesmen Berkelanjutan. Konsep Dasar, Tahapan Pengembangan dan Contoh. Surabaya: Unesa University Press.

Jacobsen, D. A. (2009). Methods For Teachy. New Jersy USA: Pearson Education.

Joyce, B \& Weil. (2000). Models of Teaching. Sixtth Edition. USA:Allyn and Bacon Publishing Company.

Kemendikbud. (2013). Implementasi Kurikulum.Peraturan Menteri Pendidikan dan Kebudayaan Republik Indonesia No. 81A Tahun 2013. Jakarta: Kementerian Pendidikan dan Kebudayaan.

Kementerian Pendidikan dan Kebudayaan. (2013).Modul pelatihan implementaasi Kurikulum 2013. Jakarta: Badan Pengembangan Sumber Daya Manusia Pendidikan dan Kebudayaan dan Penjaminan Mutu Pendidikan.

Kemp, J.E. (2007). Designing effective instruction. New York: Macmillan College Publishing Company.

Kuhlthau, C., C. (2006). Guided inquiry learning in the 21 st century, Westport, CT:Libraries Unlimited

Llewellyn. (2002). Teaching High School Science Through Inquiry. California: ASTA press.

Novak, J.D. \& Gowin D.B. (2006). Learning How to Learn. New York: Cambride University Press.

Nur, M. (2000). Buku Panduan Keterampilan Proses dan Hakikat Sains. Surabaya: Unesa University Press.

Nur, M. (2011). Model Pengajaran langsung. Dilengkapi Contoh Perangkat RPP Keterampilan Berfikir dan Pendidikan Karakter. Surabaya: Pusat sains dan Matematika Sekolah. Surabaya: Unesa University Press.

Nur, M. (2011). Strategi-Strategi Belajar. Surabaya: Penerbit Pusat Sains dan Matematika Sekolah. Surabaya:Unesa University Press.

Palinesar. A.S. \& Web. N. M. (1996). Group Processes in the Classroom In D.c. Bardiner \& R.C. Calfee Eds. Handbook of Educational Psychology. New York: Simon and Schuster Macmillan.

Plummer, J.K. (2008). Analisis of the psychometric Properties of two different Concept-map Assesment Tasks. Dissertation. Brigham Young University.

Poerwati, L.I. \& Amri, S. (2013). Panduan memahami kurikulum 2013 Sebuah Inovasi Penunjang Masa Depan. Jakarta: Prestasi Pustaka Publiser.

Purwati, E. (2012). Efektivitas Strategi Peta Konsep untuk meningkatkan Pengetahuan Prosedural dan Daya Nalar Siswa Dalam menata Dokumen (Study Eksperimen Kuasi pada Siswa kelas XI administrasi perkantoran di SMKN 1 Bandung). Tesis. UPI Bandung.

Ratumanan \& Lauren. (2011). Evaluasi Hasil Belajar Pada Tingkat Satuan Pendidikan. Surabaya: Unesa Unversity Press.

Ratumanan, G.T., dan T, Laurens. (2006). Evaluasi hasil yang relevan dengan memecahkan problematika belajar dan mengajar. Bandung:CV Alfabeta. 
Riduwan. (2010). Skala pengukuran variabel-variabel penelitian. Bandung: Alfabeta.

Ruiz-Primo. (2000). On The Use of Concept Maps as An Assesment Tool in Science. Revista Electronica de Investigation Educativa. 2(1), 29-53.

Saptorini. (2008). Pengembangan Model Pembelajaran Berbasis Inkuiri Sebagai Upaya Peningkatan Kemampuan Inkuiri Guru Kimia Kabupaten Demak. Demak. Jurnal unnes. Tersedia di @.id/njy/index.php/rekayasa/.../291 . Diakses tanggal 6 Maret 2014.

Slavin, R. E. (2011). Psikologi Pendidikan Teori dan Praktik. Jilid 1. Penerjemah samosir, M. Jakarta: Indeks.

Stoddart, T. (2000). Concept Maps As Assessments In Science In Aviry Learning A report of Methodology. The International Journal of Science Education, $22 \mathrm{p}$. 1221-1246.

Suchman, R.J. (1962). The Elementary School Trading Program In Scientific Inquiry. Report to The U.S. Office of Education. Project Tittle VII Urbana: University of Illinois.

Susanto, A (2013). Teori Belajar dan pembelajaran di sekolah Dasar. Jakarta: Kencana Prenada Media Group.

Wahyudi, A. (2013). Pengaruh Peta Konsep dalam Pembelajaran Inkuiri Terbimbing Ditinjau dari Kemampuan Bernalar siswa Kelas XI. Malang: PPS. Universitas Negeri Malang. Jurnal Pendidikan. 1 (3), 237-245.

Windura, S. (2013). $1^{\text {st }}$ Mind mapping Untuk Siswa, Guru, dan Orang Tua. Jakarta: Elex media Kompotindo Kelompok Gramedia.

Yamin, M. (2013). Strategi \& Metode dalam Model Pembelajaran. Jakarta: GP Press Group. 